Research Article

Wojciech Gis* and Maciej Gis

\title{
Overview of the method and state of hydrogenization of road transport in the world and the resulting development prospects in Poland
}

https://doi.org/10.1515/eng-2021-0039

Received Sep 15, 2020; accepted Jan 03, 2021

Abstract: National Implementation Plans (NIP) in regard hydrogenation motor transport are in place in European Union (EU) countries, e.g. Germany, France or Belgium, Denmark, Netherlands. Motor transport hydrogenization plans exist in the Japan and USA. In Poland the methodology deployment Hydrogen Refuelling Stations (HRS) developed in Motor Transport Institute is of multi-stage character are as follows: Stage I: Method allowing to identify regions in which HRS should be located. Stage II: Method allowing to identify urban centres, in which should be located the said stations. Stage III: Method for determining the area of the station location. The presentation of the aforesaid NIPS and based on that and the mentioned methodology the conditions for hydrogenization of motor transport in Poland is the purpose of this article, which constitutes its novelty. The scope of the article concerns the hydrogenization of motor transport in the abovementioned countries. With the above criteria, the order the construction in Poland of a HRS, in the order of their creation, along the TEN-T corridors is as follows: 1 - Poznan 2 - Warsaw, 3 - Bialystok, 4 - Szczecin, 5 - the Lodz region, 6 - the Tri-City region, 7 Wrocław, 8 - the Katowice region, 9 - Krakow.

The concluding discussion sets out the status of deployment HRS and FCEVs in the analysed countries.

Keywords: motor transport, hydrogen, FCEV, environment protection

\section{List of symbols and abbreviations}

Al

Aluminium

^Corresponding Author: Wojciech Gis: Motor Transport Institute, Jagiellonska 80 Street, 03-301 Warsaw, Poland;

Email: wojciech.gis@its.waw.pl

Maciej Gis: Motor Transport Institute, Jagiellonska 80 Street, 03-301 Warsaw, Poland; Email: maciej.gis@its.waw.pl

๑ Open Access. @ 2021 W. Gis and M. Gis, published by De Gruyter. (cc) BY 4.0 License
BEV

CAPEX

$\mathrm{Ca}+$

CCS

$\mathrm{CH}_{4}$

Cl

Co

$\mathrm{Cr}$

$\mathrm{Cr}^{3+}$

$\mathrm{Cu}$

$\mathrm{Cu}^{2+}$

EU

FCEB

FCEV

Fe

$\mathbf{F e}^{3+}$

HDV

HFCEV

$\mathrm{H}_{2}$

$\mathrm{H}_{2} \mathrm{~S}$

HRS

ISO

K

LDV

$\mathrm{Na}^{+}$

$\mathrm{NH}_{3}$

$\mathbf{N i}^{2+}$

NIP

NO

$\mathrm{NO}_{2}$

$\mathbf{N O}_{X}$

$\mathbf{N}_{2}$

$\mathbf{O}_{3}$

PEM

PSA

S

SAE

Si

$\mathrm{SO}_{2}$
Battery Electric Vehicle

Capital Expenditure

Calcium Ion (1+)

Carbon Capture and Storage

Methane

Chlorine

Carbon Monoxide

Chromium

Chromium Ion (3+)

Copper

Copper Ion (2+)

European Union

Fuel Cell Electric Bus

Fuel Cell Electric Vehicle

Iron

Iron Ion (3+)

Heavy-Duty Vehicle

Hydrogen Fuel Cell Electric Vehicle

Hydrogen

Hydrogen Sulfide

Hydrogen Refuelling Station

International Organization for Standardization

Potassium

Light-Duty Vehicle

sodium ion (1+)

Ammonia

Nickel Ion (2+)

National Implementation Plan

Nitric Oxide

Nitrogen Dioxide

Nitrogen Oxides

Nitrogen

Ozone

Proton - exhange membrane

Pressure Swig Adsorption

Sulfur

Society of Automotive Engineers

Silicon

Sulfur Dioxide 


$\begin{array}{ll}\mathbf{S O}_{3} & \text { Sulfur Trioxide } \\ \text { SO }_{X} & \text { Sulfur Oxides } \\ \text { TEN-T } & \text { Trans-European Transport Network } \\ \text { TSA } & \text { Temperature Swing Adsorption }\end{array}$

\section{Introduction}

The necessary transformation of the energy system places hydrogen at its core. Hydrogen can play seven significant roles in this transformation: enabling large-scale renewable energy integration and power generation, distributing energy across sectors and regions, acting as a buffer to increase energy system resilience, decarbonizing transportation, decarbonizing industrial energy use, helping to decarbonize building heat and power, providing clean feedstock for industry [1].

In July this year, the European Commission announced "A hydrogen strategy for a climate - neutral Europe" [2]. This is a strategic vision for the implementation in 2050 of “The European Green Deal” (European climate neutrality in 2050) $[3,4,4,6]$.

The Commission is today proposing a new $€ 750$ billion recovery instrument, Next Generation EU, embedded within a powerful and modern long-term EU budget. The money from Next Generation EU will be invested across three pillars, trough $€ 500$ billion in grants and $€ 250$ billion in loans to Member States: first pillar - support to Member States for investment and reforms, second pillar - kick-starting the EU economy by incentivizing private investment, third pillar - learning the lessons of the crisis [4].

This involves cooperation between public authorities, industry and civil society among others - for example within the framework of the European Clean Hydrogen Alliance, based on the European Battery Alliance [6, 7]. At the same time the aforesaid hydrogen strategy is supplemented by the concurrently announced EU Strategy for Energy System Integration [5]. Both strategies enable the accomplishment of sustainable developments goals and the objectives of the Paris Agreement [8].

Hydrogen is now mainly produced on the basis of fossil fuels, primarily based on steam reforming of methane and coal gasification, which, however, causes emissions in the $\mathrm{EU}$ of between 70 and 100 million $\mathrm{CO}_{2}$ per year. Therefore, the priority for the EU is to develop the production of renewable hydrogen, produced primarily using solar wind energy [2].

For the decarbonization of the above-mentioned sectors of the economy, at least $6 \mathrm{GW}$ of renewable hydrogen electrolysers in the $\mathrm{EU}$ (production of up to 1 million tonnes of renewable hydrogen) are planned to be installed in the first phase from 2020 to 2024. In the second phase (20252030) hydrogen will be an integral energy carrier of the integrated energy system with at least $40 \mathrm{GW}$ of renewable hydrogen electrolysers installed by 2030 (production 10 million tonnes of renewable hydrogen in the EU). In the short and medium term, necessary will be the existing hydrogen production with a strong reduction in greenhouse gas emissions using, for example, CCS - Carbon Capture and Storage. In the third phase (2030-2050) renewable hydrogen technologies will be used on a large scale for effective decarbonisation [2].

From now to 2030, investments in electrolysers could range between $€ 24$ and $€ 42$ billion. In addition, over the same period, $€ 220-340$ billion would be required to scale up and directly connect 80-120 GW of solar and wind energy production capacity to the electrolysers to provide the necessary electricity. In addition, investments of $€ 65$ billion will be needed for hydrogen transport, distribution and storage, and hydrogen refuelling stations. From now to 2050, investments in production capacities would amount to $€ 180-470$ billion in the EU. Finally, adapting end-use sectors to hydrogen consumption and hydrogen-based fuels will also require significant investments.

In the road transport sector, rolling out an additional 400 small-scale hydrogen refuelling stations (compared to 100 today) could require investments of €850-1000 million [2].

The above clearly indicates the following dynamic development of hydrogenization, including motor transport, and its scale will be decided by the current decade. It is very important for its support to build the right infrastructure in the form of HRS and to enable making the most of them. This varies from country to country.

Of those most advanced in the creation of transport hydrogenization, including automotive, this article referred to the development of hydrogenization of that transport in EU countries, i.e. Germany, France, leading in this area in the EU, but also to that development in other EU countries, i.e. Belgium, Denmark and the Netherlands. In each of these countries, a National Implementation Plan (NIP) has been drawn up relating to this scope. Reference has been made to this development in Japan, the most advanced in terms of the construction of the said infrastructure, or the USA, one of the world leaders in the development of motor transport hydrogenization, where appropriate development plans have also been developed in the aforementioned scope. The following articles will refer to other countries, in particular those with significant developments in the hydrogenization of motor transport, i.e. among others the United Kingdom, South Korea, China and Canada, which have own plans to 
develop motor transport hydrogenization. Currently, the focus is on the use of FCEV and FCEB (Fuel Cell Electric Bus). In relation to the FCEB, today taken into account are in particular city buses. However, in the long term, the use of hydrogen will also be significantly based on the use in heavy-duty vehicles equipped with hydrogen fuel cells. This is already the case in the current initial phase of their introduction, before their full commercial application.

A number of key previous publications referred to the development of hydrogenization of motor transport, includ-

Defining the purpose and scope of research: reference to International Implementation Plans in regard to hydrogenization moto transport in same countries (Germany, France, Belgium, Denmark, Netherlands, Japan and USA) and in Poland

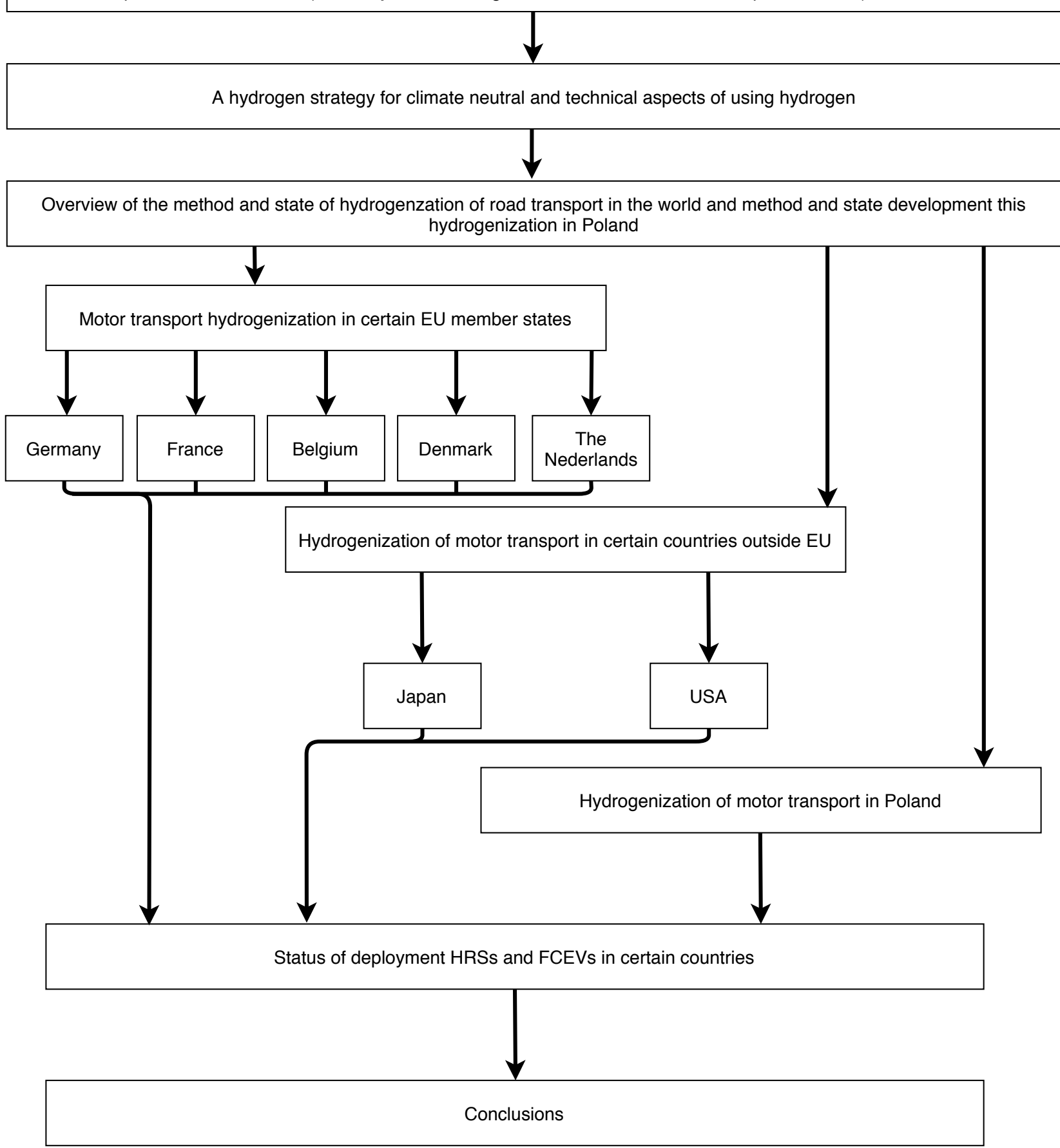

Figure 1: Research methodology. 
ing the development of refuelling infrastructure (HRS), as essential for the development of the above-said hydrogenization, but also the number, mainly of passenger cars and buses, equipped with fuel cells, e.g.:

- Hydrogen scaling up (2017 r.) and Hydrogen Roadmap Europe (2019 r.) [1, 9] or The Future of Hydrogen (2019 r.) [10]. To a lesser extent, they relate in terms of hydrogenization to NIPs of respective countries. The publication [11] referred, for example, to the total number of HRS in the world and in individual countries, as well as to the number of passenger cars, including buses (regionally), at the end of 2017, in total and in respective countries. The publication [12] provides among others - available data on the number of HRS and FCEVs (Fuel Cell Electric Vehicles) for some years from 2014 to 2030, but from a 2014 perspective, for later years. The publication [13] compiles the most important country-specific actions in the world for the development of motor transport hydrogenization in 2018, giving for some the number of HRS and FCEV in 2030.

- The publication discusses NIPs in countries such as Germany, France, Belgium, Denmark, the Netherlands, Japan and the USA, and verifies the current number and projected numbers of HRS, FCEV and FCEB.

The above publications did not take into account the circumstances of the NIP in Poland in this regard, which this article addresses.

Despite the strategic importance of developing HRS infrastructure, in the available materials, including various NIPs for the hydrogen technology developments, the explicitly formulated programming methodology for the development of these stations, has not been encountered [14].

The structure of this article is as follows: objective and scope of the article and the introduction section detailing the possible economic sectors of hydrogen use in the necessary energy transition and references - for example - to the most recent hydrogen strategy for climate neutral Europe, as well as some important - according to the authors - technical issues in the use of hydrogen (chapter 2), referred to the hydrogenization of motor transport in some EU member states (chapter 3) and some non-European countries (chapter 4) and hydrogenization of motor transport in Poland (chapter 5). Status of development HRSs and FCEVs in certain countries is presented in chapter 6 , whereas chapter 6 provides a conclusion (chapter 7). Figure 1 shows the methodology of research.
Motor transport hydrogenization plans (NIPs) exist in Germany, France or Belgium, Denmark, Netherlands, Japan and USA. Based on that and the methodology of deployment HRS developed in Motor Transport Institute the circumstances for hydrogenization of motor transport in Poland have been presented, which as highlighted in the abstract, constitutes the novelty of the article.

\section{Technical aspects of hydrogenization}

Attention should be paid to the relevant technical aspects of the use of hydrogen. Industrial methods of producing hydrogen include steam methane reforming (approx. 48\%) $-10 \mathrm{tCO}_{2} / \mathrm{tH}_{2}$, partial oxygenizing of refinery remnants (approx. 30\%), - $12 \mathrm{tCO}_{2} / \mathrm{tH}_{2}$ carbon gasification (approx. $18 \%)-19 \mathrm{tCO}_{2} / \mathrm{tH}_{2}$ and electrolysis of water (approx. 4\%) $-1 \mathrm{tCO}_{2} / \mathrm{tH}_{2}$ (renewable energy sources). Depending on the temperature, hydrogen develops in the following phases:

- gas - above boiling point of $20 \mathrm{~K}\left(-253^{\circ} \mathrm{C}\right)$,

- liquid - within the range $14-20 \mathrm{~K}$ (from $-259^{\circ} \mathrm{C}$ to $-253^{\circ} \mathrm{C}$ )

- solid - below $14 \mathrm{~K}\left(-259^{\circ} \mathrm{C}\right)[15]$.

Major contaminants identified in the operation of PEM (Proton-Exchange Membrane) fuel cells, commonly used in passenger cars and buses are:

- $\mathrm{N}_{2}, \mathrm{NO}_{x}\left(\mathrm{NO}, \mathrm{NO}_{2}\right), \mathrm{SO}_{x}\left(\mathrm{SO}_{2}, \mathrm{SO}_{3}\right), \mathrm{NH}_{3}, \mathrm{O}_{3}$; impurity source: air,

- $\mathrm{CO}, \mathrm{CO}_{2}, \mathrm{H}_{2} \mathrm{~S}, \mathrm{NH}_{3}, \mathrm{CH}_{4}$; impurity source: reformate hydrogen,

- $\mathrm{Fe}^{3+}, \mathrm{Ni}^{2+}, \mathrm{Cu}^{2+}, \mathrm{Cr}^{3+}$; impurity source: bipolar metal plates (end plates),

- $\mathrm{Na}^{+}, \mathrm{Ca}^{+} ;$impurity source: membranes (Nafion),

- Si; impurity source: sealing gasket,

- Si, Al, S, K, Fe, Cu, Cl, V, Cr; impurity source: coolants, water,

- $\mathrm{SO}_{2}, \mathrm{NO}_{2}$, CO, propane, benzene; impurity source: battlefield pollutants,

- Oils; impurity source: compressors [16].

Avoiding the possibility of contamination during the refuelling stages (last specification of contamination - oils) makes it appropriate to use oil-free compressors.

SAE J2719 Standard "Hydrogen Fuel Quality for Fuel Cell Vehicles" is aligned with the corresponding ISO standard for hydrogen fuel quality ISO/DIS 14687-2 "Hydrogen fuel - product specification - Part 2 Proton exchange membrane fuel cell applications for road vehicles) [17]. Accord- 
ing to ISO 14687-2 $[18,19]$ Hydrogen fuel index (minimum mole fraction) is equal to $99,97 \%$. Total non-hydrogen gases amount to $300 \mu \mathrm{mol} \mathrm{mol}^{-1}$. The hydrogen fuel index is determined by subtracting the "total non-hydrogen gases", in ISO 14687-2 expressed in mole percent, from 100 mole percent [20].

Pressure swing adsorption (PSA) is a non-cryogenic gas separation process able to provide $\mathrm{H}_{2}$ with a purity ranging from 99 to $99.999 \%$ [20]. For the purpose of producing $\mathrm{H}_{2}$ with $>99.99 \%$ purity for fuel cell applications (ISO 146872) the best technology is adsorption. In addition to PSA, temperature swing adsorption (TSA) can also be used to achieve even higher purities of $99.9999 \%$, but excessive power is required to perform the cold cycles making it more expensive [20].

SAE J2601 Standard is Fuelling Protocols for Light Duty Gaseous Hydrogen Surface Vehicles to ensure safe vehicle fills while maximizing fuelling performance [21-23]. It introduces two fuelling methods, known as the "lookup table" method and the "MC formula" method. The "lookup table" method is based on 44 individual tables that specify pressure ramp rates for given combinations of HFCEV onboard storage capacities (2-4 kg, 4-7 kg and 7-10 kg), station types/fuel delivery temperature (T40, T30 and T20), station/hose delivery pressure (H70 for $70 \mathrm{MPa}$ and $\mathrm{H} 35$ for 35 $\mathrm{MPa}$ ), type of vehicle dispenser interface (communication and non-communication) and the dispenser outlet. The MC method is an analytical

That uses thermodynamic properties of the FCEV tank to dynamically determine the APRR (Average Pressure Ramp Rate (MPa/min)) that controls fuelling speed [21-23]. The "MC formula" method greatly reduces fuelling time compared to the "lookup table" method at higher ambient temperatures, as well as when the precooling temperature falls on the colder side of the expected temperature window for all station types [23]. The SAE J2601 protocol establishes and maintains the fuelling process limits to ensure process safety and performance. The safety limits of the vehicle storage system (tank) are as follows: minimum gas temperature $-40^{\circ} \mathrm{C}$, maximum gas temperature $85^{\circ} \mathrm{C}$, minimum dispenser pressure $0.5 \mathrm{MPa}$, maximum dispenser pressure 87.5 MPa (70 MPa NWP (Nominal Working Pressure), maximum flow rate $60 \mathrm{~g} / \mathrm{s}$.

The SAE J2601 protocol defines specific assumption of fuelling conditions that must be met for the protocol to be used. The HFCEV storage capacity should be between 2 to $10 \mathrm{~kg}$ if its NWP is $70 \mathrm{MPa}$. The ambient temperature must be between $-40^{\circ} \mathrm{C}$ and $50^{\circ} \mathrm{C}$. The hydrogen fuel delivery temperature (at the dispenser breakaway) cannot be less than $-40^{\circ} \mathrm{C}$ or greater than $-17.5^{\circ} \mathrm{C}$ at any time during the fuelling process. The vehicle pressure at the beginning of a fill must be between $0.5 \mathrm{MPa}$ and the nominal working pressure of the vehicle ( $35 \mathrm{MPa}$ or $70 \mathrm{MPa}$ ). Finally, the hydrogen flow rate cannot be allowed to exceed $60 \mathrm{~g} / \mathrm{s}$ at any time during the fuelling process [23]. Hydrogen pressure of $100 \mathrm{MPa}$ is technically possible, the adjustment of SAE J2601 will be reasonable [24]. However, it should be taken into account that the range of FCEV depends on the type of vehicle, the capacity of $\mathrm{H}_{2}$ pressure container and the type of hydrogen pressure. By increasing the capacity and pressure of $\mathrm{H}_{2}$, the range can be increased. However, the costs will be higher and the space in the car will be smaller [15]. The transport of hydrogen is also important. For example, compressed hydrogen up to $70 \mathrm{MPa}$ can be stored in tanks of a Toyota Mirai passenger car. The total capacity of 2 tanks is $122.4 \mathrm{l}$ of hydrogen (front 60l, rear 62.41). Those containers are made of composite materials. Their walls form three layers: the internal layer is made of plastic liner (seals in hydrogen) (ensuring excellent tank tightness), the next layer is made of carbon fibre-reinforced plastic layer (ensures pressure resistance), and the external layer is made of glass fibre-reinforced plastic (protects the surface).

The automotive liquid hydrogen tank, on the other hand, consists of an external tank, a super isolator and an internal tank, as well as a safety valve, a filling line for the liquid level indicator, a shut-off valve, a radiator and an electric heater [15]. The technology of making stationary tanks is similar to the above.

Although the technological maturity of the use of liquid hydrogen is high, it is relatively little used for motor vehicles due to the still somewhat experimental scale of use in vehicles and refuelling stations using this fuel [15]. This should change with the widespread use of this fuel in heavy-duty vehicles. Hydrogen liquefication also involves high energy consumption (equivalent to $30 \%-40 \%$ of liquefied hydrogen energy) [15]. For this reason, the use of compressed hydrogen is now more common.

\section{Motor transport hydrogenization in certain EU member states}

\subsection{Germany}

A broader interest in the hydrogenization of motor transport in the Germany took place at the end of the 1990s. At that time, a number of works were carried out on the energy use of hydrogen in motor transport, its transport or distribution. An example could be the co-operation "Verkehrswirtschaftliche Energiestrategie" (VES, Transport Energy 
Strategy) between German politics and private companies which was founded in 1998. It was targeted at developing strategies to ensure a global leading role of the German car industry in alternative fuel technologies [25].

Another example can be the CEP (Clean Energy Partnership, established in 2002) emerged from the VES as a joint political initiative, lead-managed by the German Ministry of Transport and Industry. While the VES took a more theoretical approach, the CEP puts the knowledge gained into practice. CEP has three phases: 2002-2008, 2008-2010 and 2011-2016 of different tasks. For instance, the second phase was committed to the qualification of applications in daily usage, e.g. improvement of vehicle efficiency and cold-start abilities as well as a cost reduction in vehicle and infrastructure technologies. In 2014, about 85 FCEV were operated within the framework of the CEP [25].

Yet another example can be the H2-Mobility Initiative (2009), which originates from the VES. The Initiative, making it the centrepiece for the commercialization of FCEVs in Europe. The H2-Mobility initiative was transformed to a Joint Venture in 2012/13. The Initiative reviewed various options for building a Germany-wide H2-infrastructure assuming the serial production of FCEVs and public co-financing of further HRS and their development, in particular in large agglomerations. In 2012, it was expected that in 2020 there would be around 400 HRSs and approx. 150000 FCEVs (in 2030 - 1,000 HRSs and 1,800,000 FCEVs, respectively). It was also assumed that in 2023 there will be 500 HRSs operating, 500,000 FCEVs and 2 thousand FCEBs (Fuel Cell Electric Bus) [9].

In 2012 Daimler, Linde, Air Products, Air Liquide and Total agreed to invest $20 \mathrm{M} €$ in a further 36 stations up to a total of 50 stations with the support of the Federal Government (NIP) by 2015 (due to the delayed market introduction of FCVs [25].

It should be pointed out that the first public compressed hydrogen refuelling station was launched in Hamburg as early as in January 1999 and the world's first public liquid hydrogen station was launched at Munich Airport in May this year [26, 27]. However, at the end of December 2015, only 20 HRSs and 150 FCEVs were used [28].

In the result of the undertaken efforts federal government, federal states, industry and science in 2006 "National Innovation Programme Hydrogen and Fuel Cell Technology" (NIP I) was adopted, functioning in years 2006-2016, which comprised a funding volume of 1.4 billion euros (in studies applied in the area of transport 471 projects were performed and 238 demonstrative projects). A governmental National Organization Hydrogen and Fuel Cell Technology - NOW was established in 2008 to manage the programme. It also operates in the area of electrical mobility. The above projects CEP and H2-Mobility Initiative have been included among others in NIP I. NOW organisation also operates the NIP II government programme for hydrogen and fuel cell technology for the period of 2016-2026. In this second phase, only the Federal Ministry of Transport and Digital Infrastructure (BMVI) was initially investing 250 million euros until 2019 to support hydrogen and fuel cell technology for the implementation of the programme [29].

In the first stage of the development of the hydrogen refuelling infrastructure in the Germany by 2015, planned within the framework of $\mathrm{H} 2$ Mobility Initiative under the auspices of NIP I was the launch of 50 public HRS (vs. even 100 HRSs initially assumed). At the end of 2017, there were however 56 hydrogen refuelling stations in Germany, used by several hundred FCEVs (approx. 300). The construction of the aforesaid 50 HRS was completed in 2018 [30]. In the second phase of the development of this infrastructure by the end of 2020, with an investment of 350 million euro, 100 hydrogen refuelling stations are planned to be launched and by the end of 2023 (initially by the end of 2025) 400 HRSs (10 HRSs each in the 6 largest metropolises, while ensuring a maximum distance of $90 \mathrm{~km}$ between HRS on motorways. In 2030 there should be 1000 HRS with full commercialisation [31-34].

The main objective of the use of hydrogen in Germany in the case of motor transport is to reduce greenhouse gas emissions (mainly $\mathrm{CO}_{2}$ ) and energy consumption by the said transport and to increase the share of renewable energy. The targets are as follows: a 40\% reduction in greenhouse gas emissions in 2020 and $80-95 \%$ in 2050 vs 1990 for greenhouse gas emissions, and respectively a reduction by $10 \%$ and $40 \%$ in final energy consumption vs 2008 , with an increase in the use of renewable energy up to - respectively $-18 \%$ and $60 \%$ in final energy consumption [34]. This involves the production of hydrogen based on electrolysers, the power of which is likely to be greater than $10 \mathrm{GW}$ in 2030 [35].

FCEVs currently have a long range of 400-700 km with a single refuelling, with refuelling time similar to that of conventional passenger cars, and investments in the refuelling infrastructure at 20 million FCEVs are equal to $€ 40$ billion ( $€ 51$ billion for BEV - Battery Electric Vehicle), which gives FCEV an advantage over BEV $[1,36]$. In Germany, there were 87 hydrogen refuelling stations at the end of 2019 [37].

\subsection{France}

A hydrogenization development plan in France, including motor transport, was prepared by the H2Mobilité France Consortium in 2013 and envisaged significant development 
of FCEV refuelling infrastructure from 96 HRS in 2022 to 602 HRS in 2030 (in 2026-2030 with a decreasing share of HRS with a hydrogen generation capacity of $212 \mathrm{~kg} / \mathrm{d}$ in favour of HRS with a hydrogen production capacity of $420 \mathrm{~kg} / \mathrm{d}$ ) and the development of FCEVs from 23 thousand in 2022 to 773,000 in 2030, with hydrogen demand of up to 3,000 tonnes in 2022, to 89000 tonnes in 2030 and electrical energy demand from 115 GWh p.a. in 2022 to 3,251 GWh p.a. in 2030 [38].

According to the aforementioned development plan, in 2040 and 2050, the fleet of FCEV and light trucks will be 3.7 million vehicles and 7.3 million vehicles respectively, with a share of $9 \%$ and $17 \%$ in the total French market of passenger and light trucks [38]. With regard to reducing $\mathrm{CO}_{2}$ emissions, the introduction of the said fleet of hydrogen vehicles would provide in a life cycle (with an average annual mileage of $15,600 \mathrm{~km}$ and mix hydrogen production - 75\% using electrolysers) of $1.2 \mathrm{tCO}_{2}$ per year by vehicle in 2030, when the societal cost of $\mathrm{CO}_{2}$ is evaluated at 105 euro per tonne [38]. At the end of 2017, there were 19 hydrogen refuelling stations and 263 vehicles served by them in France [11]. At the end of 2019, there were 26 HRSs operating and 34 planned in France. Most of the French HRS aim at refuelling of buses and delivery vehicle fleets [39].

In 2018, presented was on the basis of an in-depth "Hydrogen scaling up" study on the use of hydrogen in key areas of the world economy a plan for the development of hydrogenization in France, including in motor transport [40]. This plan assumes among others that:

- the number of HRS in 2023 will be 140 and 400 in 2028,

- the number of passenger cars and light trucks using fuel cells will be 10,000 in France in 2023 and 200,000 vehicles in 2028, and in $205018 \%$ of used passenger vehicles and light trucks will use hydrogen, as well as $25 \%$ of the registered bus fleet and $20 \%$ of the fleet of registered heavy trucks,

- investment expenditure - for example - for the implementation of $600 \mathrm{HRSs}$ comes to 750 million euro.

The hydrogen distribution plan for the energy transition in 2018-2028 was presented by Minister for Ecological Transformation Nicolas Hulot on 01.062018 [41]. According to that plan:

- in 2023 in France there should be 5000 light trucks, 200 buses and heavy-duty vehicles equipped with hydrogen fuel cells and $100 \mathrm{HRSs}$,

- in 2028 from 20,000 up to 50,000 light trucks, from 800 to 2000 buses and heavy-duty vehicles equipped with hydrogen fuel cells and from 400 to 1000 HRSs,
- in $201718.5 \%$ of electricity was derived from renewable sources and 40-60\% of that energy should be stored,

- production of hydrogen by electrolysers is considered very important, for example Michelin plans to implement 15 electrolysers, 20 hydrogen refuelling stations and the purchase of 1000 vehicles equipped with hydrogen fuel cells (Zero Emission Valley project -Auvergne- Rhône-Alpes region),

- roughly 200 light hydrogen Hy-Kangoo trucks by symbioFC are used (price approx. 30 thousand euros). The price of $12 \mathrm{~m}$ of bus is about 450 thousand euro. Hydrogen buses are already in use in French cities.

\subsection{Belgium}

Within the framework of the European HIT-2-Corridors project in December 2015 a proposal was developed - National Implementation Plan - Hydrogen Refuelling Infrastructure Belgium [42, 43]. According to the said proposal, taking into account the average percentage of HRS stations in 2015-2020, 2020-2025, 2025-2030 in the total number of petrol stations in those years in respective countries, i.e. Germany, the UK, the Netherlands, France, Denmark, Japan, South Korea and California, it was estimated in the said proposal that in the case of Belgium with about 3.200 petrol stations, the amount of HRS refers to $0,8 \%$ (2020) via 2,3\% (2025) to 4,7\% (2030). This is completely in line with the targets in other H2-Mobility countries. Thus, in years:

- 2015-2020 there should be 25 HRSs (20 in Flanders and 5 in Walloon region),

- 2020-2025 there should be 75 HRSs (50 in Flanders and 20 in Walloon region and 5 in Brussels),

- 2025-2030 there should be 150 HRSs (100 in Flanders and 40 in Walloon region and 10 in Brussels [42, 43].

This results in overall CAPEX for HRS up to 2030 of about 170 million euros. For 2020 should be about 1.000 FCEV's in Belgium which is almost $0,02 \%$ of the total vehicle fleet. After 2020, during the early market introduction (20202025), the amount of FCEV's will grow to possibly 7.500 FCEV's. This is almost $0,15 \%$ of the market. Finally, between 2025-2030, a ramp up could emerge which results in 30.000 FCEV (0,55\% market penetration). For buses, the target is 50 buses in 2020, 250 in 2025 and 500 in 2030 [42, 43]. At the end of 2017 in Belgium there were however for example only 3 HRS (in Antwerp, Halle and Zaventem) and 21 FCEV and several hydrogen buses [11, 44]. 


\subsection{Denmark}

The beginnings of the development of hydrogenization of transport, including automotive transport in Denmark, practically started in 2001 by the creation of the "Danish Hydrogen and Fuel Cell Partnership", in which the Working Group "National FCH Transport Strategy Group” in 2008 prepared a national program "National R\&D and demonstration strategy for FCH Transport”. Between 2011 and 2014, a number of projects were implemented, co-financed by FCH-JU (The Fuel Cells and Hydrogen Joint Undertaking). In 2014, the "National Implementation Plan (NIP) for hydrogen refuelling infrastructure" was established [45]. The first activities for FCEVs were undertaken in 2001 and for HRS - in 2006.

In March 2014, 17 FCEVs were in operation, mainly Hyundai iX35 cars and there were 3 HRS operating (in September 2014, the 4th was built). The focus was on supplying passenger cars with hydrogen at a pressure of 70 MPa. It was assumed that in 2025 electrical energy would be used, generated from hydrogen in 4.8and in $2030-15.7 \%$ and $50 \%$ in 2050, replacing that derived from conventional fuels. Total electricity generation from renewable sources was expected in 2050. At the end of 2017, 10 HRSs (85 FCEV and several FCEB) were operated in Denmark [11].

The development scenarios of the FCEV fleet were made dependent on its dynamics. Thus, in the scenario assuming high development of the FCEV, it was assumed that in 2050 there would be 1.4 million vehicles ( $50 \%$ of the passenger car fleet). In the medium-sized development scenario of FCEV in the said year there were to be 1.1 million FCEVs (37.5\% of the passenger car fleet), and 0.7 million FCEV ( $25 \%$ of the passenger car fleet) in the low development scenario of FCEVs in 2050. Those variants assumed respectively in the high development scenario for FCEV the use of 100 000 FCEVs in 2015 (4\% of the passenger cars fleet), in the medium-sized development in 2025 operation - 50000 FCEVs (2\% of the said fleet) and in the low development scenario operation in $2025-25000$ (1\% of the said fleet) [45].

Whereas, in 2025, with regard to HRS in the scenario assuming high development of FCEVs around 200 HRSs should be operated, roughly 1000 HRSs in 2050, and in the scenarios of low and medium development, in 2025 approx. 100 HRSs and in 2050 - 500 HRSs [45]. In Denmark analyses are made of the central, and local production of hydrogen. Electrolyser capacity in 2025, 2035, and 2050 is 88 MW, 579 MW and 1063 MW respectively, used in 85\% [45].

\subsection{The Netherlands}

The Ministry of Infrastructure and Environment of the Netherlands at the end of 2011 initiated works on a programme on the hydrogenization of transport, and the resulting conclusions were presented in 2013. The programme consisted of four phases:

Phase 0 (2000-2012; research and development), Phase 1 (2012-2015; market preparation), Phase 2 (2015-2020; market introduction and yet market preparation) and Phase 3 (after 2020; mass production and yet market preparation). This programme was concretized in the EU project - The Hydrogen Infrastructures for Transport (HIT), where 4 phases were also adopted. These were: Phase 1 (2014-2017; market preparation, 2-20 HRS, 1,500 hydrogen vehicles, access by $20 \%$ of the population), Phase 2 (2018-2023; early market introduction, 20-50 HRSs, 1,500-15, 000 hydrogen vehicles, access by $50 \%$ of the population), Phase 3 (2024-2030; full market introduction, 50-200 HRSs, 15,000-125,000 hydrogen vehicles, access by $90 \%$ of the population), Phase 4 (after 2030; mass market, 1000-1400 HRSs, >2.5 million hydrogen vehicles, access by $100 \%$ of the population). Development of the HRS network: initial network of $20 \mathrm{HRSs}$ with $210 \mathrm{~kg} /$ day stations, upgrade of initial stations to 420 $\mathrm{kg} /$ day 5 years after installation, and installation additional $420 \mathrm{~kg} /$ day base on need for HRS capacity resulting from hydrogen demand and network utilisation [46, 47].

At the end of 2017 in the Netherlands functioning were only 3 hydrogen refuelling stations and 34 hydrogen vehicles and several buses [11].

According to Dutch H2Platform (May 2018):

- by 2020 there should be: 20 HRS, 2000 FCEVs, 100 FCEBs, 500 vans, 20 trucks,

- whereas in 2030 there should be 216 HRSs, according to: Scenario Low 132000 hydrogen vehicles, Scenario Mid 375000 hydrogen vehicles, Scenario High 696000 hydrogen vehicles, 300000 FCEV, 65000 LCVs (Light Commercial Vehicle), 7700 trucks and 1 700 buses. Governmental Subsidies end 2026, total Capital expenditures (Capex) 2018-2030 €725 million $[48,49]$.

In July 2017, the Ministry of Economic Affairs and Climate Policy asked TKI Gas (gas network organisation in the Netherlands) to manage the process to define the outlines of a roadmap for hydrogen [48]. The report was based on among others - the findings of the "Hydrogen scaling-up" study, referring to the same areas of energy transition as those cited in this study, and assumed was a reduction in greenhouse gas emissions by $80-95 \%$ in 2050 vs 1990 [48]. The report addressed a wide range of issues related to its 
use. Attention was drawn to the need to develop ways of producing it based on renewable energy, distribution (refuelling infrastructure) or use in heavy-duty vehicles [50, 51].

This year a governmental document "Government Strategy on Hydrogen" has been published, stating that the National Climate Agreement includes an ambition to scale up electrolysis to approximately $500 \mathrm{MW}$ of installed capacity by 2025 and 3-4 GW of installed capacity by 2030 . However, in order to support the targets, set out in the National Climate Agreement (50 HRS, 15,000 hydrogen vehicles and 3,000 heavy-duty hydrogen vehicles by $2025 ; 300,000$ hydrogen vehicles by 2030), a cooperation agreement with various stakeholders will be signed in this year. Electricity will be obtained for electrolysis from offshore wind farms and the gas network will also be used for hydrogen transmission [52].

\section{Hydrogenization of motor trans-port in certain countries outside EU}

\subsection{Japan}

The Council for a Strategy for Hydrogen and Fuel Cells, comprising experts from industrial, academic and government sectors, compiled the Strategic Roadmap for Hydrogen and Fuel Cells in June 2014 [53].

The roadmap seeks to realize a hydrogen-based society on a step-by-step basis under the following three-phase program, carefully considering both short and long periods of time required to overcome technological challenges and secure economic efficiency [53]:

- Phase 1: Dramatic expansion of hydrogen use. By expanding the use of fixed fuel cells and fuel cell vehicles (FCVs) dramatically, Japan will capture the global market for hydrogen and fuel cells in which it leads the world.

- Phase 2: Full-fledged introduction of hydrogen power generation and establishment of a large-scale hydrogen supply system (by the second half of the 2020s).

- Phase 3: Establishment of a $\mathrm{CO}_{2}$-free hydrogen supply system on a total basis (by around 2040). Japan will combine hydrogen production with CCS or use hydrogen from renewable energy to establish a $\mathrm{CO}_{2}$ free hydrogen supply system.

Based on later progress in hydrogen use development, the roadmap was revised in March 2016 to include the path to and quantitative targets for expanding residential fuel cells (Ene-Farms) and FCVs and making hydrogen stations independent.

The Ministerial Council on Renewable Energy, Hydrogen and Related Issues held (April 2017) its first meeting to discuss initiatives for expanding renewable energy and realizing a hydrogen-based society. It then adopted a plan to decide on a fundamental strategy within the year that would allow the government to be united in promoting initiatives that ensure Japan becomes the first country in the world to realize a hydrogen-based society. The plan was specified in the Investments for the Future Strategy 2017 (Cabinet Decision on June 9, 2017). Based on the Strategic Roadmap for Hydrogen and Fuel Cells that mainly spells out goals to be realized by around 2030, this strategy provides the directions and vision that public and private sectors should share with an eye on 2050 [53].

According to the report published by the Ministry of Trade and Industry, the number of used vehicles with hydrogen drive is to increase from 2.3 thousand at the end of 2017 (presently approx. 3500 FCEVs) to 200 thousand in 2025 and 800 thousand in 2030, and the number of HRS functioning to the end of 2017 is expected to increase from respectively 92 (presently 130 HRSs) to 320 in 2025 [53, 54]. FC buses launched regular services in 2017. Seeking to increase the number of FC buses including those for regular services to 100 by 2020 and to 1200 by 2030, the government will consider wider use of FC buses in accordance with hydrogen station development and in cooperation with local governments. Commercial trucks number more than 3.2 million units in Japan (2017), with greater potential to consume hydrogen than buses (230 000 units) [53].

To further encourage the use of hydrogen and fuel cells among others in area FCVs, FC trucks, FC buses, the use of hydrogen and fuel cells in this area, it is of value to share global aspirational goals such as " 10 million hydrogenpowered systems" and " 10 thousand Hydrogen Refuelling Stations (HRS)", " $10 \%$ of global hydrogen production is 'clean' in 10 years" (“Ten, Ten, Ten" in Ten) up to 2030, as indicative, nonmandatory and collective goals to help incentivize and mobilize the private sector and invest community, is a very interesting initiative of Japan in 2019 [55].

\subsection{USA}

The United States of America (USA) are among the countries of the most advanced technology, oriented on the use of hydrogen for energy purposes. The existing U.S. fleet of about 240 million gasoline-fuelled light-duty vehicles 
(LDVs) is served by a network of 120 000-150 000 retail gasoline refuelling stations $[56,57]$.

That suggests a ratio of about 2000 gasoline vehicles for every gasoline station. By comparison, at the end of 2016, 33 retail HRSs served approximately 1000 FCEVs in the United States [58]. Private companies, government agencies, and research institutions own and operate another 26 HRSs [56]. Eight HRSs are serving 25 active fuel-cell transit buses, and deployment of another 46 fuel cell buses is planned [58]. An estimated 50 fuel cell electric buses were also in operation in Europe in 2017, 25 in California and about in other US states $[9,59]$. California enjoys the dominating position in terms of hydrogenization of motor transport. In 1990, the State of California launched an ambitious agenda to introduce zero-emission vehicles to reduce pollution and improve public health. In 1999, the California Fuel Cell Partnership (CaFCP) formed as a public-private collaborative to address technical barriers to bringing fuel cell electric vehicles to the commercial market and comply with California Air Resources Board zero-emission vehicle regulation [60].

On April 20, 2004, California began a course towards a sustainable transportation energy future when Governor Arnold Schwarzenegger signed Executive Order S-7-04 creating the California Hydrogen Highway Network. On the same day, he designated the University of California-Davis' hydrogen station (demo) as Station no 1 of the California Hydrogen Highway Network. The development of the California Hydrogen Highway Network was pursued in three phases. This Blueprint Plan focuses on completion of Phase 1 in the 2010 timeframe. Phase 1 calls for the deployment of 50 to 100 publicly accessible hydrogen refuelling stations sited to provide convenient fuelling for hydrogen vehicles. An estimated 2000 hydrogen vehicles can be in operation by 2010 on the way to achieving 20000 hydrogen vehicles in operation on California's roads and freeways for full-scale commercialization of hydrogen technologies [61].

In February 2009, the California Fuel Cell Partnership published an "action plan" that detailed the precommercial phase (2012-2014) roll-out of hydrogen stations and vehicles in clusters. This cluster concept builds on early work pioneered by the Department of Energy (DOE) through their Technology Validation Program as well as the FiveCities Program sponsored by the South Coast Air Quality Management District [60-62].

In January 2018, Governor Brown signed Executive Order B-48-18, setting ambitious targets of 200 hydrogen fuelling stations and 250000 electric vehicle chargers to support 1.5 million zero-emission vehicles (ZEVs) on California roads by 2025, on the path to 5 million ZEVs by 2030 network [60].
Newport Beach hydrogen station represents a significant milestone. It is the first hydrogen fuelling station in the US upgrade fully funded by private industry (public from 2018 r.). Six public HRSs were built (with approx. 179 - 200 FCEVs). As of June 30, 2018, there were 36 retail hydrogen refuelling stations open across the state of California [62]. The vast majority of these early HRSs is concentrated in California, which has a total of 61-62 operational and underconstruction stations [56, 63]. As of May 28, 2019, California's hydrogen fuelling network consisted of 41open retail HRS [63].

Californian's FCEV fleet at the end of 2019 consisted of 5923 vehicles on the road according to CARB's analysis of the Department of Motor Vehicles (DMV) registration records available. The public-private California Fuel Cell Partnership published its vision of one thousand stations and one million FCEVs by 2030 in its 2018 Revolution document [64]. Auto manufacturer-provided projections for on-the-road FCEVs are 26900 in 2022 and 48000 in 2025. Predicted on the goal of reaching 200 HRS by 2025 and the 1000 station and one million FCEV by 2030 [64].

The US also initiated a public-private collaboration known as H2USA, with approximately 50 partners committed to enabling hydrogen infrastructure for FCEV adoption in the US [59]. Each of the three scenarios developed Urban Markets, State Success, and National Expansion - varies by the rate and geographic scope of HRS network investments.

Differences between the scenarios provide insights into infrastructure development trends that could result from the combined influences of market support mechanisms, consumer demand, and successful coordination and planning among automakers, fuel providers, station owners, investors, and government agencies [59].

For example, in a State Success scenario in 2025, FCEV stock is: 144,100 vehicles and $420 \mathrm{HRS}$, while in 2035 it is 2,800,000 FCEVs, 2,100 HRS, and in 2050 it is 36,000,000 FCEVs and 11,800 HRS [45]. There are multiple means of achieving FCEV market growth beyond California [59].

\section{Hydrogenization of motor transport in Poland}

The territorial accessibility for hydrogen vehicles is determined by the availability of hydrogen refuelling infrastructure, in the first place along with the TEN-T network $[14,65]$.

Within the European Project HIT-2-Corridors, as a result of the verification in Polish conditions, the original method developed for determining the initial location of the hydrogen refuelling station in Poland in the pre-commercial 
phase (2020-2030), the said location has been indicated along with the order of investment, taking into account above all the freedom to move around Poland of FC vehicles visiting Poland and transiting our country between other EU countries [14].

The methodology developed is of a multi-stage character. Individual steps leading to the designation of the location of hydrogen refuelling stations in Poland (as the methodology alone seems to be universal) are as follows:

Step I: Method allowing to identify regions in which the hydrogen refuelling stations should be located in the first place. The parameters considered include among others: average GDP per capita, average population density (inhab. / $\mathrm{km}^{2}$ ), the number of people living in the largest cities in the region, out of the cities with more 250 thousand inhabitants, average traffic volume of passenger cars on the national roads of international significance running through the region (passenger cars/24 hours).

Step II: Method allowing to identify urban centres, in which should be located the said stations. The parameters considered include among others: average distance of the cities, over 250 thousand inhabitants, from the place of hydrogen manufacture (acquisition), average distance of the cities, over 250 thousand inhabitants from the nearest hydrogen refuelling station located outside Poland, number of taxies in the city, number of municipal transport buses.

Step III: Method for determining the area of the station location [14]. The parameters considered are: results of locating the stations in question obtained in stage I and II, and relying on the results of the measurement of average traffic volume of passenger cars on the roads leading to these cities or on selected road junctions located near these cities, traffic flow intensity of passenger cars was included on the roads leading to the following cities: Warsaw, Poznan, Krakow, Wroclaw, Katowice (Upper Silesia conurbation), Tri-City, Szczecin, Lodz, Bialystok.

With the above criteria, the order in the construction of hydrogen refuelling stations in Poland is as follows: 1 - Poznan 2 - Warsaw, 3 - Bialystok, 4 - Szczecin, 5 - the Lodz region, 6 - the Tri-City region, 7 - Wroclaw, 8 - the Katowice region, 9 - Krakow.

The movement area of cars using fuel cells based on 9 base hydrogen refuelling stations (in total 30) situated in the national TEN-T road network by 2030, will cover the territory of Poland. Full commercialization of the hydrogen technology in Poland according to the analyses and studies: the years 2040-2050 respectively: 200-600 hydrogen refuelling stations, financial expenditures for the construction of the hydrogen refuelling infrastructure in the order of 155 190 million $€$. Assumptions: 600 thousand - 2 million cars, $500-1000$ buses, and 100-300 thousand cars transiting Poland annually.

When comparing the development of hydrogenization of motor transport in Japan, Germany and the US in terms of the number of vehicles equipped with hydrogen fuel cells and HRS, noticed can be currently the definite preponderance of the number of those vehicles used in the US, whereas in terms of the number of used HRS it is contrarily - the number of HRS in Japan and Germany is presently greater.

By 2030 the planned number of vehicles in Japan and in USA is similar (roughly 800 thousand in Japan and 1 million in the USA), and the number of HRS in the US is to be more than three times greater in 2030. Germany is planning to develop the HRS infrastructure as Japan and USA. The plans of France - at least as regards the number of FCEVs, there are like Japan. In Poland, there is practically no hydrogenization of motor transport. The barrier for its development is currently the lack of HRS infrastructure and production on a wider scale of purified hydrogen essential for powering hydrogen fuel cells even though about 1 million tons of hydrogen are produced for industrial purposes. Still, its purification requires an expensive PSA technology [14].

\section{Status of deployment HRSs and FCEVs in certain countries}

The HRS number and FCEV number status analysed in Germany, France, Belgium, Denmark, the Netherlands, Japan, California, USA and Poland is currently as follows:

Germany: 2015 (20 HRS, 150 FCEV); 2017 (56 HRS, 300 FCEV); 2019 (87 HRS); 2020 (100 HRS, 150000 FCEV; 2023 (400 HRS); 2030 (1000 HRS, 1800000 FCEV).

France: 2017 (19 HRS, 263 FCEV); 2019 (26 HRS+34HRS planned); 2023 (100-140 HRS, 10000 FCEV); 2028 (4001000 HRS, 200000 FCEV); 2030 (602 HRS, 773000 FCEV).

Belgium: 2017 (3 HRS, 21 FCEV); 2020 (75 HRS, 1000 FCEV); 2025 (150 HRS, 7500 FCEV); 2028 (30 000 FCEV). 
Denmark: 2017 (10 HRS, 85 FCEV); 2025 (100-200 HRS); 2050 (500-1000 HRS, 700 000-1 400000 FCEV).

The Netherland: 2017 (3 HRS, 34 FCEV); 2020 (20 HRS, 2000 FCEV); 2025 (50 HRS, 15000 FCEV); 2030 (216-1000 HRS, 300000 FCEV).

Japan: 2017 (97 HRS, 2300 FCEV); 2020 (130 HRS, 3500 FCEV); 2025(320 HRS, 200000 FCEV); 2030 (900 HRS, 800000 FCEV).

California: 2017 (33 HRS, 1000FCEV); 2019 (41 HRS, 5923 FCEV); 2023 (26900 FCEV); 2025 (200 HRS, 48000 FCEV); 2030 (1000 HRS, 1000000 FCEV).

USA: 2025 (420 HRS 144100 FCEV); 2040 (2100 HRS, 2800 000 FCEV, 2050 (11 800 HRS, 36000000 FCEV).

Poland: 2020 (1 HRS, 10 FCEV); 2025 (5 HRS, 1000 FCEV); 2030 (30 HRS, 15000 FCEV); 2040 (200 HRS, 600000 FCEV); 2050 (600 HRS, 2000000 FCEV).

Status of deployment HRSs and FCEV in years 2015-2050 shown in Figure 2 and Figure 3.

In 2030, the number of the planned HRS in Germany is ten times higher than at present (1000 HRS), as is the

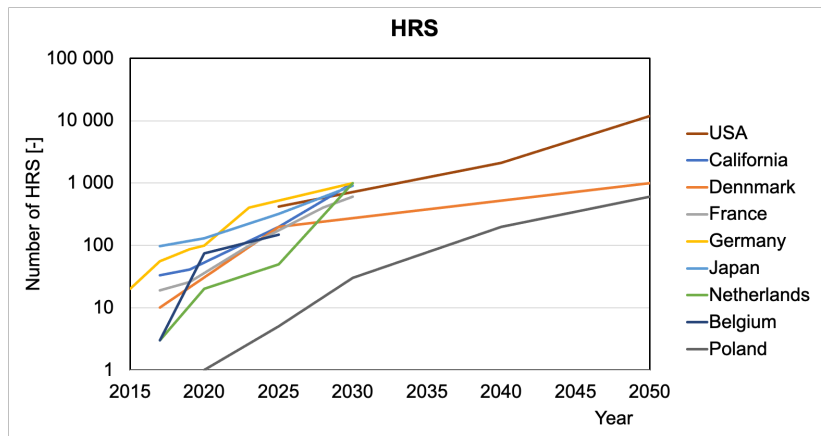

Figure 2: Actual and assumed number of HRS in 2015-2050

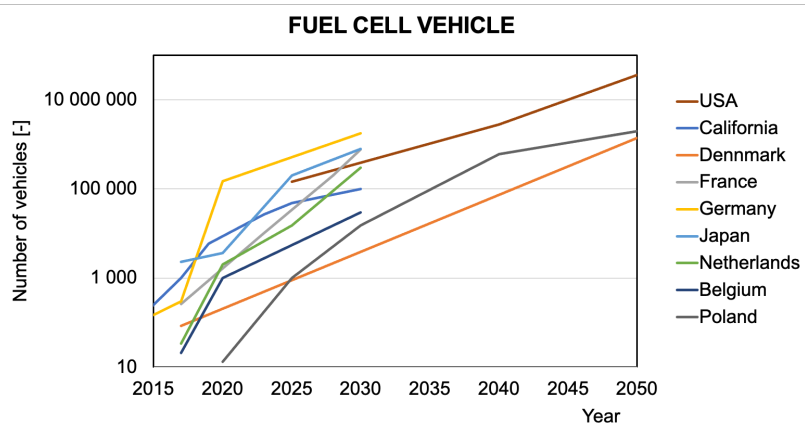

Figure 3: Actual and assumed number of FCEV in 2015-2050 number of FCEVs equipped with fuel cells. In Japan, HRS are projected to increase by almost seven times ( $900 \mathrm{HRS}$ ), and the number of FCEVs as stated above to 800,000 vehicles in 2030. California is projected to have 1,000 HRS and 1,000,000 FCEVs in 2030. Those countries/regions currently dominate the world in terms of the development of motor transport hydrogenization, and the data collected indicate that this trend is likely to continue in 2030. However, for example, China's or Korea's plans for 2030 in this area are similar, among others the use of 1000 HRS each [13]. According to the Hydrogen Council FCEV (cars) could represent almost $3 \%$ of new vehicles sales in 2030, ramping up to about $35 \%$ in 2050, for total sales of 4 million vehicles in 2030. In the markets leading global FCEV adoption, Germany, Japan California, and South Korea, almost every $12^{\text {th }}$ car sold in 2030 could be powered by hydrogen. However, it is important to highlight that for a fully developed infrastructure, 2500-3500 FCEVs per station are expected [20]. In the USA, Japan, Germany, this is, for example, currently 90 , 30,10 FCEVs per station $[1,9]$. This points to the possible delays in the implementation of the adopted assumptions. Reduction in the traffic flow in urban areas, and also the use of fuel cell vehicles will contribute to improving air quality [66].

\section{Conclusions}

For the development FCVs is necessary, first of all, to develop the infrastructure HRS for refuelling them, but also to ensure the transport of hydrogen, using natural gas transmission infrastructure or its on-site production with the use of electrolysers, enabling a significant reduction in $\mathrm{CO}_{2}$ emissions in hydrogen production through electricity from renewable energy sources (e.g. offshore wind farm operation or the use of photovoltaic cells). In a number of countries, activities in the area of developing mainly the HRS infrastructure have been well advanced over the last decade. That is forcefully taking place in terms of increasing the number of these stations in Japan, which is the world leader in this regard, in Germany currently ranking second, or the USA (California) ranking third, as well as in France (ranking second in Europe), but also in other smaller countries, i.e. Denmark, the Netherlands or Belgium, as set out in this article. All these countries have plans for the use of hydrogen, which are addressed in this article. There are no HRS in Poland yet. However, developed in Motor Transport Institute in Warsaw have been "Circumstances of the National Plan for Hydrogenization of Road Transport in Poland", also presented in this article. In accordance with 
this plan the location and the order in which hydrogen refuelling stations in Poland should be built is as follows: 1 Poznan 2 - Warsaw, 3 - Bialystok, 4 - Szczecin, 5 - the Lodz region, 6 - the Tri-City region, 7 - Wroclaw, 8 - the Katowice region, 9 - Krakow. This plan can form the context of the so-called National Hydrogen Implementation Plan (NIP). Large national fuel and energy companies, but also other entities, are currently preparing for the construction of HRS. The construction of the HRS infrastructure in Poland is a necessity.

\section{References}

[1] Hydrogen scaling up, A sustainable pathway for the global energy transition, Hydrogen Council. 2017 Nov.

[2] Communication from the Commission to the European Parliament, the European Council, the European Economic and Social Committee and the Committee of the Regions. A hydrogen strategy for a climate - neutral Europe. COM (2020) 301 final. Brussels, 8 July 2020.

[3] Communication from the Commission to the European Parliament, the European Council, the European Economic and Social Committee and the Committee of the Regions. The European Green Deal. COM(2019)640 final. Brussels, 11 December 2019.

[4] Communication from the Commission to the European Parliament, the European Council, the European Economic and Social Committee and the Committee of the Regions. Europe's moment: Repair and Prepare for the Next Generation. COM(2020)456 final. Brussels, 27 May 2020.

[5] Communication from the Commission to the European Parliament, the European Council, the European Economic and Social Committee and the Committee of the Regions. Powering a climate - neutral economy: An EU Strategy for Energy System Integration. COM(2020)299 final. Brussels. 08 July 2020.

[6] European Clean Hydrogen - European Commission. Available from: https://ec.europa.eu/growth/industry/policy/europeanclean-hydrogen-alliance-en.

[7] European Battery Alliance - European Commission. Available from: https://ec.europa.eu/growth/industry/policy/europeanbattery-alliance-en.

[8] Paris Agreement. Official Journal of the European Union L 282/4. 19th October 2016.

[9] Hydrogen Roadmap Europe. A sustainable pathway for the European energy transition. FCH (2019). Available form: doi: $10.2843 / 341510$.

[10] The Future of hydrogen. Seizing today's opportunities, Report prepared by the IEA for the G20. Japan. 2019 June.

[11] Closer look at the deployment of fuel cell EVs as of Dec. 2017. Available from: https://www.ieafuelcell.com/fileadmin/publicat ions/AFC_TCP_survey_status_FCEV_2017.pdf.

[12] Weeda M, de Wilde H, Wurster R, Schaap G, Wallmark C, Mulder $F$, et al., Towards a comprehensive hydrogen infrastructure for fuel cell electric cars in view of EU GHG reduction targets, HIT European Project, 2014.

[13] Dorociak M, Tomecki M. Wodór. Paliwo przyszłości. Warszawa 2019. ISBN: 978-83-954071-3-0.
[14] Gis W, Menes E, Waśkiewicz J, et al. Circumstances of the national plan for hydrogenization of road transport in Poland. ITS, Warsaw (2015).

[15] Surygała J, Wodór jako paliwo. WNT, Warszawa (2008).

[16] Cheng X, Shi Z, Glass N, Zhang L, Song D, Liu Z-S, et al. A review of PEM hydrogen fuel cell contamination: Impacts, mechanisms, and mitigation. Journal of Power Sources 165(2007)739756. Available from: doi: 101016/j.jpowsour.2006.12.012.

[17] National Institute of Standards and Technology (NIST). Frequently Asked Questions. 2019 Sep.

[18] IS014687-2:2012, Hydrogen fuel-product specification-part 2: proton exchange membrane (PEM) fuel cell applications for road vehicles, International Organization for Standarization, Geneva, Switzerland.

[19] IS014687-2:2019, Hydrogen fuel-product specification-part 2: proton exchange membrane (PEM) fuel cell applications for road vehicles, International Organization for Standarization, Geneva, Switzerland.

[20] Bacquart T, Murugan A, Carré M, Gozlan B, Auprětre F, Haloua F, et al. Probability of occvuirence of ISO 14687-2 contaminants in hydrogen: Principles and examples from strem methane reforming and electrolysis (woter and clor-alkali) production processes model. International Journal of hydrogen Energy (2018), Available from: doi: https://doi.org/10.1016/j.ijhydene.2018.03.084

[21] Society of Automotive Engineers (SAE),2016, Fueling Protocols for Light Duty Gaseous Hydrogen Surface Vehicles (Standard J2601_201612), SAE International.

[22] Society of Automotive Engineers (SAE),2020, Fueling Protocols for Light Duty Gaseous Hydrogen Surface Vehicles (Standard J2601_202005). SAE International.

[23] Reddi K, Elgowainy A, Rustagi N, Grupta E. Impact of hydrogen SAE J2601 fueling methods on fueling time of light-duty fuel cell ecectric vehicles. International Journal of Hydrogen Energy. 2017 May. Available from: doi: 10.1016/j.ijhydene. 2017.04.233.

[24] Zogopoulops E. Hydrogen: Is this future? (Part II). National Technical University of Athens. 2020 July.

[25] Lemke R. Market Introduction of Hydrogen Fuel. Berlin (2016).

[26] Wasserstoff - Spiegel Nr.1/99. Available from: https://www.dwvinfo.de/wp-content/uploads/2015/06/wss9901.pdf.

[27] Wasserstoff - Spiegel nr.2/99. Available from: https://www.dwvinfo.de/wp-content/uploads/2015/06/wss9902.pdf.

[28] Annual Report 2015 NOW GmbH. Available from: https://www. now-gmbh.de/en/knowledgefinder/now-annual-report-2015/.

[29] Annual Report 2018 NOW GmbH. Available form: https://www.no w-gmbh.de/wp-content/uploads/2020/09/now_annual_report_ 2018-1.pdf.

[30] Bonhof K, Thorsten H, Butsch H. 50 Hydrogen Refuelling Stations in Germany. Within the frame of the National Innovation Programme Hydrogen and Fuel cell Technology. IFP/IEA/ITF Workshop. 2012 Nov.

[31] Butsch H. HRS Infrastructure in Germany and Europe - Current Activities. Washington. 2014 June.

[32] Bundesministerium für Verkehr und digitale Infrastruktur: Nationaler Strategierahmen über den Aufbau der Infrastruktur für alternative Kraftstoffe. 2016 Nov.

[33] Thorsten H. Deployment of Hydrogen and Fuel Cell Technology in Germany. EHEC. Spain (2018). NOW GmbH.

[34] Nitsch J. Was dedeutet ein Klima- und was bedeutet ein Energieziel für den Verkehrsector? Zweites Fachgespräch in Rahmen des Fachdialogs zur Mobilitäts- und Kraftstoff strategie des 
BMVBS. Berlin. 17th Juli 2012.

[35] Bonhof K. The renewable and Clean Hydrogen Challenge of Mission Innovation. Hydrogen Ministerial Meeting. Tokyo, Japan. 23rd October 2018.

[36] Robinius M, Linssen J, Grube T, Reuss M, Stenzel P, Syranidis K, Kuckertz P, Stolten D. Comparative Analysis of Infrastructures: Hydrogen Fueling and Electric Charging of Vehicles, Jürlich Forschungzentrum. Energie \& Umwelt/Energy \& Environment (Vol. 408).

[37] 12th Annual assessment of H2stations.org by LBST. Press Release. 19th February 2020.

[38] H2Mobilité France, Study for a Fuel Cell Electric Vehicle national deployment plan. Mobilité Hydrogéne. France (2017).

[39] 12th Annual assessment of $\mathrm{H} 2$ stations by Ludwig-BölkowSystemtechnik (LBST). Press Release. 19th February 2020.

[40] Développons l'Hydrogéne pour l'économie française, Étude prospective, Associacion française pour l'hydrogéne et les piles á combustible (AFHYPAC). Paris (2018).

[41] Plan de déploiement de l'hydrogéne pour la transition énergétique, Rapport de Ministére de la Transition Écologique et Solidaire. Paris (2018).

[42] Van der Laak W, Martens A, Neis S. National Implementation Plan Hydrogen Refuelling Infrastrukture Belgium - H2 Mobility Belgium. WaterstofNet. 2015 Dec.

[43] Van der Laak W. H2 Mobility Belgium. A plan for the development of a hydrogen refuelling infrastructure and implementation of fuel cell electric vehicles in Belgium. Available from: www.hyer. eu/wp-content/uploads/2016/04/7--Hydrogen-Road-Tour.pdf

[44] François I. National Policy Paper - Belgium. HyLAW Project. 2018 Dec.

[45] National Implementation Plan for Hydrogen Refueling Infrastructure, 3rd final edition. 2014 June.

[46] Weeda M., NIP - NL, Version June 2014. ECN 2014.

[47] Weeda M., Economic analysis of HRS network build-up in the Netherlands, Petten. ECN-E -15-067. 3rd July 2015.

[48] Weeda M. New impetus for hydrogen in the Netherlands, Information day. Hydrogen Innovation Mission to the Netherlands, Embassy of the Kingdom of the Netherlands. Tokyo. 30 May 2018

[49] Dencher R. Demand gathering \& demand creation. Information day. Hydrogen Innovation Mission to the Netherlands. Embassy of the Kingdom of the Netherlands, Tokyo. 30 May 2018.
[50] Gigler J, Weeda M. Outlines of a Hydrogen Roadmap. TKI NIEUW GAS, Topsector Energie (2018).

[51] Van Wijk A, et al. The Green Hydrogen Economy in the Northeern Netherlands, Groningen. The Netherlands. 2017 October.

[52] Government Strategy on Hydrogen, Ministry of Economic Affairs and Climate policy. 6th April 2020.

[53] Kawai T. FCV Development and Initial Market Creation-Mission to Hydrogen Society. FC EXPO 2018 Technical Conference. 28th Feb 2018 - 2nd Mar 2018.

[54] Ikeda T. Technology Development for the Next Generation Hydrogen Refueling Station. Hy SUT, FC EXPO 2018 Technical Conference. 28th Feb 2018 - 2nd Mar 2018.

[55] Summary of 2nd Hydrogen Energy Ministerial Meeting-Global Action Agenda of Tokyo Statement (draft). 2nd Hydrogen Energy Ministerial Meeting. Tokyo. 25 September 2019.

[56] Alternative Fueling Station locator and 2014 Public Retail Gasoline Stations by Year. AFDC (Alternative Fuels Data Center). 2017.

[57] 2015 Retail Fuels Report. NACS (Association for Convenience\& Fuel Retailing. 2015.

[58] Cobb, J. December 2016 Dashboard (2017). Available from: HybridCars.com

[59] Melaina M, Bush M, B., Muratori M, Zuboy J, Ellis S. National Hydrogen Scenarios, Where, and When? Prepared by the National Renewable Energy Laboratory for the H2USA Locations Roadmap Working Group (2017).

[60] A California Road Map: The comercialization of Hydrogen Fuel Cell Vehicles. California Fuel Cell Partnership, West Sacramento.

[61] California Hydrogen Bluprint Plan. CARB (Vol. 1). 2005 May.

[62] California Fuel Cell Partnership. A California Road Map. Bringing Hydrogen Fuel Cell Electric Vehicles to the Golden State. California Fuel Cell Partnership. West Sacramento. 2012 July.

[63] 2018 Annual evaluation of Fuel Cell Electric Vehicle Deployment \& Hydrogen Fuel Station Network Development. CARB. 2018 July.

[64] 2019 Annual evaluation of Fuel Cell Electric Vehicle Deployment \& Hydrogen Fuel Station Network Development. CARB. 2019 July.

[65] Wallmark C, Schaap G., Hydrogen infrastructure for transport. Facts and conceptual plan for Sweden. Sweco (2014).

[66] Jrew B, Msallam M, Momani L. Strategic Development of Transportation Demand Management in Jordan. Civil Engineering Journal (Vol.5) 1. 2019 Jan. Available from: doi: http://dx.doi.org/10. 28991/cej-2019-03091224. 